Research Report No. 4/2010

\title{
Income Splitting and Gender Equality: The Case for Incentivizing Intra-Household Wealth Transfers
}

Lisa Philipps

Osgoode Hall Law School of York University, lphilipps@osgoode.yorku.ca

Follow this and additional works at: http:// digitalcommons.osgoode.yorku.ca/clpe

\section{Recommended Citation}

Philipps, Lisa, "Income Splitting and Gender Equality: The Case for Incentivizing Intra-Household Wealth Transfers" (2010).

Comparative Research in Law \& Political Economy. Research Paper No. 4/2010.

http://digitalcommons.osgoode.yorku.ca/clpe/73 


\section{Comparative Research in Law \& Political Economy}

Lisa Philipps

\section{Income Splitting and Gender Equality: The Case for Incentivizing Intra-Household Wealth Transfers}

EDITORS: Peer Zumbansen (Osgoode Hall Law School, Toronto, Director, Comparative Research in Law and Political Economy, York University), John W. Cioffi (University of California at Riverside), Nassim Nasser (Osgoode Hall Law School, Toronto, Production Editor) 
CLPE Research Paper 04/2010

Vol. 06 No. 1 (2010)

\title{
Lisa Philipps \\ Income Splitting AND Gender Equality: The CASE for InCENTIVIZING INTRA-Household WeALTH TRANSFERS
}

\begin{abstract}
In all countries that use the individual as the basic unit of taxation, tax policy makers must contend with the problem of spousal income splitting and the dilemma it poses for gender equality. On the one hand income splitting opens a back door to joint taxation of couples, with its troubling labour market disincentives for second earners. Yet attempting to prevent this type of avoidance planning by ignoring inter-spousal transfers for tax purposes disrespects women's individual agency over property to which they hold legal title, and may close off one source of economic power for those who do the bulk of unpaid work. This tax policy thus issue engages fundamental, normative debates about the meaning of gender equality and whether it is possible to enhance women's access to markets while also valuing and compensating their unpaid contributions. The paper argues that a way through this dilemma is to differentiate between forms of income splitting that enhance the economic autonomy of a lower-earning spouse and those that entail no meaningful sharing of economic power but merely reduce tax for the transferor. While the former should be aggressively constrained, a gender-equality case can be made for more liberal treatment of genuine intra-household transfers, if combined with other measures that reduce the costs to second earners of entering paid labour. The paper criticizes recent Canadian reforms that expand the scope for notional income splitting, without demanding any real redistribution of underlying assets or income.
\end{abstract}

Key words: taxation, gender, wealth, income splitting, equality

JEL classification: K34

\author{
Lisa Philips \\ Associate Professor \\ Associate Dean (Research, Graduate Studies and Institutional Relations) \\ Osgoode Hall Law School \\ York University \\ E-mail: Iphilipps@osgoode.yorku.ca
}




\title{
Income Splitting and Gender Equality: The Case for Incentivizing Intra-Household Wealth Transfers
}

\author{
Lisa Philipps*
}

In this chapter I examine the problem of income splitting under an individual tax unit and Canadian legal developments that have expanded the scope for such tax planning by spouses. Income splitting poses a dilemma for tax policy analysts concerned with gender equality because, left unchecked, it opens a back door to joint taxation, with its troubling impact on labour-market incentives for secondary earners, who are mainly women. Yet ignoring intrafamilial transfers in order to prevent income splitting may disrespect women's individual agency over property to which they hold legal title, and it may close off a potential source of economic power for those who do the bulk of the unpaid work in a household. This tax policy dilemma engages fundamental, normative debates about the meaning of gender equality and whether it is possible to enhance women's access to markets while also valuing and compensating their unpaid contributions.

A way through this dilemma is to differentiate between forms of income splitting that enhance the economic autonomy of a lower-earning spouse and those that entail no meaningful sharing of economic power but merely reduce tax for the transferor. The key problem with recent Canadian changes is that they confer the tax benefits of income splitting without any requirement that the transferor share the underlying income or assets with the lower-income partner. While this form of tax planning should be aggressively constrained, a gender-equality case can be made for more liberal treatment of genuine intra-household transfers. (For an analysis of the tax/benefit implications of redistribution of personal income within both heterosexual and gay/lesbian households, see Warman and Woolley, chapter 11 this volume.)

A number of objections may likely be made to this proposal to differentiate between good and bad forms of income splitting. In particular, feminist tax scholars may be concerned that tolerating any income splitting at all will reinforce women's financial dependency on male partners and discourage them from pursuing their own market incomes. In responding to this

\footnotetext{
* Professor Lisa Philipps joined the faculty of Osgoode Hall Law School in 1996 after teaching at the University of Victoria (1991-95) and the University of British Columbia (1995-96). She teaches in the Tax area and has published on numerous topics in taxation law and fiscal policy. Her research frequently examines the links between taxation, social justice, and gender equality.
} 
concern, I argue that reducing labour-market barriers should be one objective but not the exclusive focus of tax reform from a gender-equality perspective. Drawing on feminist scholarship outside the tax field, I suggest that fiscal policy should also be crafted with a view to enhancing the autonomy of those who invest their energies in providing unpaid care. Designing rules about income splitting that encourage genuine redistribution of control over household resources would contribute modestly toward meeting this goal, at least for women with relatively affluent partners. However, I recommend that this be complemented by other tax and spending reforms that would offset the erosion of revenues resulting from income splitting, provide caregivers with access to alternative sources of public support and fund childcare and other programs that reduce the costs to women of entering the paid workforce.

\section{The Dilemma Of InCOME SPLITTING: The CANADIAN EXAMPLE}

The policy challenge of income splitting is closely related to a country's choice of tax unit. Since the adoption of its first federal income tax in 1917, Canada has always defined the taxpayer as the individual or corporate 'person' (Income Tax Act: s 2). The individual unit has been extensively eroded over time by family-related concessions and by the use of a joint unit for purposes of tax-delivered benefits (Lahey 2005: 74-76; Law Commission of Canada 2001: 7289). However, it has survived as a basic structural feature of Canadian income tax despite repeated challenges by supporters of joint marital or familial taxation (Lahey 2000: 40-44). In the 1960s, both the Royal Commission on Taxation (better known as the 'Carter Commission') and the Royal Commission on the Status of Women recommended a switch to family unit taxation (Royal Commission on the Status of Women in Canada 1970; Royal Commission on Taxation 1966). In the 1990s, social conservative advocacy groups and politicians lobbied for various forms of tax relief for single-earner couples with children, including a wholesale shift to joint filing (Philipps 2002: 64-70). Among the stated reasons that policy makers have given for rejecting such proposals and for maintaining the individual tax unit is the unfairness and negative labour-market incentives of joint taxation for women as secondary earners (Benson 1969; House of Commons Standing Committee on Finance 1999).

Academic opinion in both Canada and the United States has largely validated this judgement. Many scholars have concluded that joint taxation tends to discourage women from entering the paid workforce or from spending more time on paid labour because it raises the marginal tax rate on a couple's lower-earning partner, usually a woman whose employment is socially constructed as more discretionary than the man's (see, for example, Blumberg 1971; Brooks 1996; Lahey 1995; McCaffery 1992). In addition, tax scholars have criticized the propensity of joint taxation to reward couples with a traditional gendered division of labour with a 'marriage bonus', whereas two-earner couples suffer a 'marriage penalty', especially if the spouses earn roughly the same amount (Brown 1997; Forman 1996). Administratively, joint filing can also result in 'innocent spouses' being stuck with tax liability for household income over which they 
have no legal control (Kahng 2004). In addition, a joint unit privileges couples over singles and privileges some personal relationships over others that do not enjoy the same degree of legal recognition because, for example, they are not conjugal or are not heterosexual (Brooks 1996: 63; Infanti 2009). For all these reasons, tax policy analysts interested in questions of gender equality have overwhelmingly argued against joint taxation.

Unfortunately, choosing an individual unit does not necessarily resolve the concerns raised by joint taxation. All countries adopting individual taxation must contend with the incentives it creates for income splitting, which creates some of the very same problems more often associated with joint taxation. Canadian tax policy makers, for instance, have waged a long battle to design effective anti-avoidance rules to prevent income splitting (Donnelly, Magee and Young 2000). The principal strategy has been to ignore certain intra-familial property transfers by attributing passive income back to the transferor for tax purposes (Income Tax Act: ss 74.174.5). These so-called attribution rules have never been more than partial, as they explicitly tolerate some forms of tax planning. ${ }^{1}$ Moreover, it has not been easy to enforce the spirit of the attribution rules through the courts in the face of tax-planning arrangements designed to circumvent them.

Perhaps the widest loophole was opened by the Supreme Court of Canada when it upheld a socalled dividend-sprinkling arrangement, whereby a spouse received special non-voting shares on incorporation of a family holding company (Duff 1999; Neuman $v$ Minister of National Revenue 1998). Although the husband controlled the corporation through his ownership of the voting shares and influenced the distribution of dividends, the Court refused to apply the attribution rules on the basis that the corporation was a separate person and the husband was never entitled to the dividends that the board of directors had declared on his wife's shares. In response to this decision, the government introduced a 'kiddie tax', which imposes the highest marginal rate on private corporation dividends received by an individual who is under 18 throughout the taxation year (Income Tax Act: s 120.4). However, because it applied only to minors, this reform still permitted spousal dividend sprinkling, now a popular method of income splitting for those with significant income-generating assets and access to expert planning advice..

The election in 2006 of a Conservative minority government has reignited the public debate over income splitting, as there is significant support for income splitting among Conservatives. This support is reflected in the party's official Policy Declaration, which states:

\footnotetext{
${ }^{1}$ For example, capital gains can be split with minor children; passive income can be shifted to children once they reach 18 years of age; passive income may not be attributed if a spouse or child paid fair market value consideration for an underlying property; and spousal registered retirement savings plans (RRSPs) may be used to split income between spouses.
} 
We support the elimination of all tax disadvantages for families and those who care for children at home. It recognizes the economic value of stay at home parents, and supports the introduction of tax fairness measures such as income splitting for couples with children. (Conservative Party of Canada 2008a: 7)

This resolution has not yet been adopted as government policy, perhaps because doing so would be costly. According to one estimate, the Canadian government would lose over $\$ 2$ billion per year if it extended income splitting to all couples with children-and almost $\$ 5$ billion if it did so for all couples (Library of Parliament 2007: 5). However, the 2006 budget took a first step toward permitting more income splitting by allowing taxpayers to report up to one-half of their private pension income on their spouse's or common-law partner's tax return (Income Tax Act: s 60.03). This is unprecedented; Canadian taxpayers have never before been permitted to engage in this form of income splitting, which is only notional, because it is purely a function of how tax returns are filled out. Previously, income splitting had always required a transfer or other restructuring of legal title to property or income. Pension income splitting can now be accomplished without any change of legal control over the actual pension income, not even to the extent necessary to cover the spouse's additional tax liability (Woolley 2007).

The pension income splitting rules are as close to a joint return as has ever been possible in Canada. Any employment or other income earned by the spouse will be stacked on top of the pension income reported on her return, creating the same type of market barrier as a joint unit. The provisions also allow tax to be levied on 'innocent spouses' who have no access to the underlying income. Although the measure currently applies to only one source of income (and only to taxpayers over 55), it established a precedent. Indeed, the Conservatives have already promised to extend this model of income splitting to all sources of income for families in which one spouse works less than full-time in order to care for a child or an adult with a disability (Conservative Party of Canada 2008b: 8). ${ }^{2}$

Following their re-election with another minority, the Conservative government created a new Tax Free Savings Account (TFSA), which also has an income-splitting component (Income Tax Act: s 146.2). Taxpayers may make non-deductible contributions of up to $\$ 5,000$ per annum to a TFSA, with no limit on total contributions. Investment income and capital gains earned on contributions are tax exempt, as are all withdrawals from the account. Most importantly for present purposes, gifts to a spouse or common-law partner that are used to fund a TFSA are exempt from the attribution rules (Income Tax Act: s 74.5(12)(c)). This concession effectively provides one-earner couples with access to two TFSAs, provided they have the means to save more than $\$ 5,000$ each year.

Reaction to these developments by feminist scholars and gender-equality advocates has been strongly negative (see House of Commons Standing Committee on the Status of Women 2008). For example, a coalition of activists and academics (including the author) working with the

\footnotetext{
${ }^{2}$ As of writing, the Conservative government had not yet moved to implement this promise.
} 
Canadian Feminist Alliance for International Action (FAFIA) called for the repeal of the pension income splitting rules and opposed their extension to more couples for the following reasons:

- The tax savings will be received mainly by higher-income men.

- Income splitting discourages women's paid workforce participation by increasing the tax rate on any income earned in the market.

- Income splitting biases the tax code in favour of couples with very unequal incomes and against other family forms, including single parents, unattached individuals and couples with more equal incomes.

- Dependent spouses/common-law partners receive no direct benefit, and in fact will suffer additional burdens, because they are liable for the tax but have no legal entitlement to the underlying income.

- The gradual extension of income splitting to cover all couples would be so costly as to preclude more effective and equitable programs to support families and caregivers (Canadian Feminist

Alliance for International Action undated: 11; see also Weir 2007; Woolley 2007).

Notably, these points overlap substantially with the criticisms usually levelled against joint filing. Canadian economist Jonathan Kesselman has made similar arguments regarding why either joint taxation or full splitting of employment income would be unfair to two-earner couples and would reduce women's labour supply in ways harmful to their full equality (Kesselman 2008: 25-34). Similarly, in the United States, Lawrence Zelenak has argued in favour of an individual unit but has opposed the idea of recognizing inter-spousal assignments of earned income under such a system because it would recreate the labour-market disincentive of joint taxation since, as he points out, 'the wife's income will still be stacked on top of the husband's, and she will be discouraged from working' (Zelenak 1994: 380). I argue in the balance of this chapter that concerns about discouraging women's paid work through income splitting are valid but should be tempered by equally valid concerns about the need to encourage intra-household redistribution and to give unpaid caregivers greater control over household economic resources.

The strong feminist opposition to recent tax reforms in Canada should be understood in context as a reaction to the specific forms of income splitting being promoted by the Conservative government, which is perceived generally as hostile to equality norms. This image was reinforced by several high-profile spending cuts and other policy moves targeting gender equality programs, as reviewed by Kathleen Lahey in chapter 1 of this volume (see also Brodie and Bakker 2008). In other contexts, tax scholars have sometimes argued that income splitting may be quite consistent with gender-equality goals. This perspective is elaborated below, with a view to developing a feminist approach that distinguishes the most harmful forms of income splitting from those which could be desirable if combined with other tax and spending reforms that enhance women's economic autonomy. 


\section{What Income Splitting Rules Would Best Promote Gender Equality?}

A gender equality case can be made for allowing some types of income splitting between conjugal partners, specifically where there is an actual transfer of legal and beneficial title to property or income. However, several concerns and caveats attend even this preferred form of income splitting. While the basic analysis presented here could apply to any country that taxes conjugal partners as individuals, I concretize the arguments by describing specific reform proposals for Canada. The discussion will be organized around three claims that are typically made to support the argument for allowing more income splitting on gender equality grounds: (1) that such a system would encourage more equal sharing of economic resources between men and women, (2) that it would respect women's agency as property owners and (3) that it would recognize women's unpaid contributions to household welfare. The analysis is predicated on the assertion that gender equality is no less legitimate a measure for evaluating tax policy than are the more familiar criteria of vertical and horizontal equity among different groups defined by income level, non-discretionary needs or choice of economic activity ( $c f$ Zelenak 1994: 380, 385). However, tax policy can address itself to gender equality only if rules are designed with an awareness of intra-household impacts and of the relative treatment of paid and unpaid economic activities undertaken by partners in a marriage or common-law relationship (both of which are recognized in Canadian tax law as discussed in chapter 11 by Warman and Woolley).

\section{A. INCENTIVIZING INTRA-HOUSEHOLD REDISTRIBUTION}

Commentators have asserted that the Canadian attribution rules, which ignore inter-spousal gifts and even some fair market value sales for income tax purposes, have 'the effect of discouraging husbands from transferring family property to their wives during marriage and thus achieving a more equitable distribution of wealth' (Brooks 1996: 74; see also Kesselman 2008: 24). Conversely, it has been suggested that 'when tax liability follows legal ownership of incomes and property, individual taxation of people in relationships promotes economic sharing' (Lahey 2005: 26; see also Gann 1980: 50-51; Zelenak 1994: 384-87). Claire Young recommended that empirical research be undertaken in Canada to assess whether repealing the attribution rules would actually result in more asset transfers from men to women (2000: 45, 48-49). Since then, a U.K. study has found evidence of just such an effect (Stephens and Ward-Batts 2004). The U.K. switched from joint to individual taxation in 1990 and allowed interspousal transfers without any attribution of income from the transferred property. Stephens and Ward-Batts examined the relative shares of investment income reported by higher- and lower-income spouses before and after the reform and found 'strong evidence that households did indeed take advantage of this opportunity for tax avoidance through income shifting', though most households did not exploit its full potential (2004: 2005-2006). In addition, economist Herbert Schuetze found evidence that self-employed men in Canada are more likely than their counterparts in the U.S. to allocate salary, wages or profits to their wives for income 
tax purposes, providing further empirical support for the view that income splitting incentives impact on the distribution of ownership rights within households (2006).

However, income splitting can promote this behavioural response only if it is conditioned upon a transfer of legal and beneficial title to wealth or income. Joint tax provisions which presume that household income is shared have the opposite effect: 'Giving people who do not share incomes or property the tax benefit of presumed sharing eliminates any incentive they might otherwise have to share' (Lahey 2005: 26). As Woolley stated in discussing the recent Canadian developments, '[n]ominal or notional splitting of pension income ... discourages real transfers of ownership and control' (2007: 613). These comments highlight the crucial distinction between income splitting that is based on actual sharing of control over resources, versus that which is based on a reallocation of income for tax purposes only. While the first is potentially gender equalizing, the second merely ratifies existing distributions of economic power within households. Kesselman has argued that the notional pension income splitting rules may in fact result in a more equitable gender distribution of resources because the partner with the lower tax rate must give consent before pension income can be shifted to her return, and this should increase her power to bargain for a share of the income (2008: 22). However with this approach the onus rests entirely on the financially dependent spouse to wrest control over household resources through a process of private bargaining in which power differentials of many kinds can still be expected to shape the outcome. At best, one could imagine a savvy and relatively empowered spouse insisting on enough income to cover the additional tax liability as well as a portion of the higher after-tax income obtained through income splitting. By comparison, making income splitting conditional on a transfer of underlying assets would create a much stronger incentive for richer spouses to transfer title to income-producing property which would increase the transferee's economic power and security over the longer term.

If Canadian tax policy makers sought to incentivize intra-household transfers, they would therefore have to repeal both the notional pension income splitting rules and the attribution rules that ignore real transactions between spouses. One caveat is that in order to avoid attribution of future income, the property transfer itself should be taxed on a current basis so that any accrued gain is realized in the hands of the transferor spouse. This would not only limit the revenue loss from allowing more income splitting; it would also reinforce the incentive for sharing ownership within marriage by encouraging property-owning spouses to transfer appreciating assets early, before significant gains had accrued.

\section{B. RespeCting WOMEN's AgENCY}

A second argument in favour of recognizing genuine inter-spousal transfers is the need to respect women's agency as legal rights holders. Ignoring these transactions seems inconsistent 
with the basic principle of individual taxation - that people should be taxed on income which they legally control, and it 'fails to recognize the autonomy of the spouse receiving the property (usually the wife)' (Brooks 1996: 74; see also Duff 1999: 379). Similarly, Lahey comments that women are too often treated as mere puppets in tax planning transactions (2000: 119).

A common objection to this view is that inter-spousal transfers may be purely formalistic, reflecting no change in de facto decision-making power. This concern must also underpin the argument that income splitting reduces the progressivity of the tax system, as this assumes the income really belongs to the transferor in some economic sense despite legal title being held by the transferee. One way to address the issue of informal control would be to enact administrative and anti-avoidance rules that established criteria for ascertaining whether the transferee was the true owner of the transferred property (Lahey 2000: 119; Philipps 2002). It would be important to require spouses to submit some form of written evidence of their contractual arrangements with their tax returns (Gann 1980: 63). In addition, there are many precedents within tax systems worldwide of rules that look beyond the form of a transaction to assess its economic substance. In Canada, for example, control of a corporation for some purposes is defined not only by the traditional de jure test of majority ownership of voting shares but also by a de facto test that considers whether a person exercises control 'directly or indirectly in any manner whatever' over the corporation (Income Tax Act: s 256(5.1)). De facto control can include a situation where a single creditor is allowed to withdraw all of the corporation's financing by demanding repayment of a loan on short notice (Canada Revenue Agency 2001: paras 19-23). Another rule that could be adapted to apply to inter-spousal transfers is the provision that denies the charitable donation credit for so-called 'loanback' arrangements, where a donor uses any property of a charitable entity within five years after making a donation to that charity (Income Tax Act: s.118.1(16)). This provision applies, for instance, if a private foundation lends money back to a donor, even if the loan is at a market rate of interest. In addition, Canada already has a rule that prevents income splitting through revocable trusts, which are defined very broadly (Income Tax Act: s 75(2)). If the trust property may revert to the settlor at any future time, or if the settlor has any right to determine or even consent to distributions of trust property to others, then all the income and capital gains realized by the trust are attributed back to the settlor. ${ }^{3}$ These examples show that for many purposes, Canadian tax policy makers have been prepared to distinguish substantive changes of ownership from those that are merely superficial tax avoidance devices.

Kesselman objects that such anti-avoidance rules would be costly and intrusive to apply in the case of inter-spousal transfers (2008: 24) However, this criticism could be directed toward any anti-avoidance rule that employed broad standards such as 'reasonableness' which require

\footnotetext{
${ }^{3}$ I disagree with Zelenak's argument that all transfers to a spouse via a trust should be treated as ineffective for tax purposes (1994: 387). Such a blanket rule would risk unfair exclusion of spousal trusts established purely for non-tax reasons, such as a desire to protect assets from either spouse's commercial creditors.
} 
interpretation, rather than bright line tests. Such standards constitute an essential tool for reducing avoidance precisely because they inject some flexibility to deal with new and unforeseen transactions, and create some uncertainty as to how far the rules may be stretched by tax planners (Edgar 2008: 874; Royal Commision on Taxation 1966: 552-567). Anti-avoidance rules thus serve as deterrents to aggressive tax planning, even in cases where they are not directly applied or enforced by revenue authorities.

Absent some form of blatant retention of de facto control over the use of assets, transfers of legal and beneficial title should be treated as tax effective on the basis that transferees are rational agents with the capacity to exercise their legal rights directly or through the process of bargaining with a spouse over consumption decisions. Empirical evidence supports the view that women tend to enjoy greater power over household financial decisions and feel less guilt about spending money when they have a stream of income that is legally their own (Burton, Phipps and Woolley 2007; Kornhauser 1993: 80-91). The studies emphasize that couples are extremely diverse in terms of the extent to which they share decision-making power about how income will be spent, managerial responsibility for banking, and the actual consumption of income. However Kornhauser concluded after reviewing her own and other empirical studies on intra-household financial management that "[d]espite the presence of joint accounts and a belief in resource sharing, control of the money generally still resides with the earner" (1993: 90). If the income is derived from property the title-holding spouse can exert control over both the income stream and the underlying asset, further increasing her chances of financial autonomy. As Zelenak argues, 'owners of wealth can always determine how to employ that wealth. Even if . . . owners cede some control over the consumption of their income by marrying, they still have control over the source of the income (as well as control over whether to stay married)' (1994: 357).

Even in cases where a transfer of title does not alter substantive power relations within a relationship, legal ownership may become more important on relationship breakdown. Canadian family law provides for property equalization upon divorce but formal rights are often difficult for a non-titled spouse to enforce in practice for a host of reasons-including lack of access to costly legal advice or to courts in order to establish or enforce a claim; the difficulty of tracing assets that may be owned outside the country; pressures to trade child custody for a lesser share of property; the exclusion of some intangibles like professional degrees and licences from what is considered divisible property; and the legal uncertainty surrounding others such as unvested pension plan rights (Bala 1989; Grassby 2004; Langer 1994; Poirier and Boudreau 1992; Law Commission of Ontario 2008). Moreover statutory property equalization regimes do not apply to common-law partners in most provinces, making title even more important in determining the post-relationship distribution of assets for these couples (Law Commission of Ontario 2008: 39; Mossman 2008). Thus, encouraging intra-household transfers promotes the long-term financial security of a lesser-earning spouse or partner, even where the 
transferor continues to exercise a degree of informal influence over the use of property or income while the relationship subsists.

\section{VALUING WOMEN'S UNPAID LABOUR}

An argument frequently advanced to justify income splitting is that it recognizes the value of women's unpaid contributions. In considering this claim, it is worth distinguishing between unpaid caregiving for children or other dependents on the one hand and, on the other hand, unpaid work that is done informally within family businesses or to assist employees. Elsewhere I have described this latter form of activity as 'unpaid market labour' because it contributes directly to the generation of market income (Philipps 2008a, 2008b). I argue below that while Canadian tax rules should make it easier to deduct amounts paid to compensate a family member for informal assistance in a business or job, using income splitting as a means of compensating unpaid caregivers is more problematic from a gender-equality perspective.

With respect to unpaid market labour, many sociological studies have documented the roles that family members play in the operation of small businesses and professional firms and in directly assisting with employment duties of their spouses or other relatives (reviewed in Philipps 2008a: 92-98). Spouses may perform tasks that are easily recognizable as a contribution to business operations or management or to the fulfillment of the other spouse's employment obligations. A spouse may also serve in a capacity such as social host or community ambassador for an organization that is owned by or employs the other spouse. One scholar has used the term 'two-person career' to describe middle-class jobs in which spousal participation is expected or desired in order to generate goodwill, develop commercial relationships or simply provide backup for the paid worker (Papanek 1973). Recent studies suggest that the flexibilization of labour markets and working practices and the rise of selfemployment and micro-businesses have ensured ongoing and perhaps rising demand for this unpaid market labour within many families (see eg. Baines et al 2002; Baines and Wheelock 1998; Danes and Olsen 2003; Eardley and Cordon 1996: 111; Rowe and Hong 2000). While more empirical research is required to determine the full extent of unpaid market labour contributed to different economies, I have argued that existing evidence is sufficient to justify the assumption that most paid workers rely to some degree on this form of direct support for their market activities (Philipps 2008a: 101).

Anti-avoidance rules designed to prevent income splitting may actually discourage payment of an informal family assistant for her or his services. For example, historically, Canadian income tax legislation imposed a presumption that spouses were not business partners for tax purposes (Income Tax Act: s 74(5); Philipps 2008a: 77). While this rule was repealed in the late 1970s, revenue administrators and courts remained sceptical in some cases toward claims that spouses had a commercial partnership, even in the face of evidence of a wife's extensive 
involvement in a business (see, for example, Cullen v. Canda 1985; Kuchirka (M.) v. Canada 1991; Sedelnick Estate v. Minister of National Revenue 1986). It is particularly difficult under Canadian law for an employee to deduct wages or fees paid to a spouse who assists in their work. Such costs may be deducted only by an employee who is 'required by the contract of employment' to hire and pay an assistant (Income Tax Act s 8(1)(i)(iii)). Thus, even where there is clear factual evidence that a spouse has rendered valuable services to assist his or her employee-spouse in performing job duties and even when the employer knew of and permitted this arrangement, any compensation paid to the spouse is non-deductible unless mandated by the employee's contract. Revenue authorities have stated as a matter of administrative policy that this condition will 'ordinarily' require an express term in a written employment contract but that it may also be satisfied 'where the taxpayer can establish that it was tacitly understood by both parties (the taxpayer and the employer) that such payment was to be made by the taxpayer and was, in fact, necessary under the circumstances to fulfill the duties of the employment' (Canada Revenue Agency 1994: para 1). However, it is not clear what will suffice as evidence of such a tacit understanding.

The courts have taken different views of this question. In one recent case, the Tax Court of Canada held that a branch manager for investment advisor Merrill Lynch could not deduct a salary paid to his wife, as his written contract of employment was silent on the need for an assistant, though the employer had signed a separate form confirming that an assistant was required (Morgan v Canada 2007; see also Prince $v$ Canada 2000). Even if a contractual term had been established, the Court held, the wife's salary of $\$ 35,000$ in one year and $\$ 52,000$ in another was unreasonably high, given that some of her time billed was spent attending social functions, particularly in the month of December. The decision clearly reflects a concern about tax avoidance:

I have no doubt that Ms. Morgan did some useful work for her husband during the two years under appeal, but it appears that the amounts that she invoiced and was paid were driven at least as much by income-splitting objectives as by any contractual arrangement. (para 10)

Other judges have more easily accepted that spousal assistance may be tacitly necessary in order for an employee to carry out his or her job successfully, despite the lack of any reference to this need in the formal contract of employment. A good example is Schnurr $v$ R. (2004), where the Court allowed the taxpayer to deduct a $\$ 30,000$ salary paid to his wife for secretarial and client relations work, including making contacts in the community to generate clients for her investment advisor husband (see also Longtin v. R. 2006). Yet even the most liberal interpretation of the statutory rule does not permit the deduction of payments to a spouse who is participating in the work purely because the employee finds this helpful or efficient as a means of carrying out the job-or needs help to deal with a heavy workload (see, for example, Sauvé v R. 2006, Emery v Canada 2003). 
The unfairness of this regime is highlighted by the fact that business proprietors have a much broader scope for deducting wages or fees paid to family members. These expenses may be deducted just like any others that are incurred 'for the purpose of earning income' from the business, subject to a reasonableness test (Income Tax Act: ss 9(1), 18(1)(a), 67). The courts have also conferred significant discretion on business owners in setting the amount of family salaries, which need not be limited to the market rate for an equivalent non-family employee (Cie Idéal Body v. R. 1989; Maduke Foods Ltd. v R. 1989). While the current rules for business owners may be too generous, they do encourage the redistribution of profits to spouses and other relatives involved with the business, especially by male business owners (Schuetze 2006). A similar regime should be adopted for employees whose spouses help them carry out job duties (cf. Kesselman 2008: 28). I suggest it is not even appropriate to describe commercially reasonable compensation of a family assistant as 'income splitting', as this suggests a gratuitous payment purely driven by tax-avoidance motives. While there may be a tax incentive for an individual to employ their spouse, this alone does not negate the income-earning purpose of the arrangement or the value of the services provided.

A possible criticism of my proposal is that it would encourage women to work for their husbands instead of seeking independent employment. However, a spouse's involvement in the work of a primary breadwinner should not be regarded stereotypically as merely a form of subjugation or gender oppression. For some women at some times, collaboration in a family enterprise may provide better opportunities and work-life balance, and indeed more economic power, than the regular labour market (Philipps 2008a). Neither, however, should such arrangements be romanticized as somehow free of the conflicting interests and hierarchies of family life. Household inequalities are reinforced by a tax regime that discourages fair compensation of spouses for their informal market work by denying deductibility for tax purposes. Liberalizing the rules would not only encourage redistribution of control over market income within households but would also help to degender market work symbolically by acknowledging that it is frequently produced through the joint labour of spouses.

Using income splitting as a mechanism to recognize the value of unpaid caregiving is more problematic. For instance, some commentators have suggested allowing taxpayers to deduct actual payments to a spouse who is providing unpaid care to dependents (Duff 2000: 73-74) or simply extending the notional pension income splitting rules to all couples (Mintz 2008: 17). While some such proposals openly promote a patriarchal model of the family with more sharply defined gender roles (eg, Szabo 1997), others present it as a route to greater equality within relationships. Undoubtedly, the failure of public policy to value the work of caregivers is significantly linked to women's ongoing economic inequality. Yet I would argue that promoting more income splitting of any kind is a problematic strategy for addressing this issue. When a spouse directly assists an employee or entrepreneur to produce income, these are marketoriented services that primarily benefit the individual income earner. By contrast, unpaid caregiving provides more significant benefits to society at large. Inter-spousal transfers cannot 
be the main way of recognizing these contributions because that would leave primary caregivers dependent on the goodwill of individual breadwinners. Rather, a system of refundable tax credits or other state transfers is needed to increase the autonomy of primary caregivers by providing an alternate source of economic security. In Canada, such a system could be financed by repealing the spousal credit and other dependency credits delivered to primary earners and discussed by Casey Warman and Frances Woolley in chapter $\mathrm{x}$ and replacing them with a refundable credit paid directly to caregivers (Law Commission of Canada 2001: 73). This approach would have the advantage of reaching single caregivers and those living in lower-income households, who receive little or no benefit from income splitting, or indeed those whose affluent spouses are not interested in intra-household redistribution.

Some feminist tax scholars have objected to caregiver subsidies, even if delivered directly to the intended beneficiaries, because they strengthen the already significant incentives for many women to engage in unpaid rather than paid work (see, for example, Lahey 2005: 41-42). This view is consistent with the literature reviewed earlier in this chapter on the choice of tax unit, in which the overriding concern has been to reduce barriers to women's paid labour.

Strategies to demarginalize caregiving work have received far less attention within tax scholarship. While improving women's labour-market opportunities is obviously a crucial dimension of gender-equality struggles, feminist scholars working outside the tax field have increasingly argued that this needs to be tempered with efforts to value caregiver work and to assign it more equally to men and women. Joan Williams, for example, has discussed the failure of a 'full commodification' strategy, focused singlemindedly on equalizing employment opportunities, to achieve gender-equality goals (Williams 2000: 40-48). Among other problems, she points out that this strategy glosses over the discrimination and poor working conditions that many women face in the labour market and the relative satisfaction and solidarity they may derive from their family work, a perspective that has been voiced especially by many women of colour and working-class women. Similarly, Nancy Fraser has argued that a 'universal breadwinner' model of gender equality that values labour market access above all else fails to address the problem that women continue to do the bulk of unpaid household work, even when they are employed full time (Fraser 1997: 41-68). If feminist tax scholars do not directly address the need to value unpaid caregiving, they risk ceding this ground to a social conservative movement that has a clearly defined politics of promoting one-earner families(Luxton and Vosko 1998: 52).

Biases in taxation and other biases against women's paid labour do need to be addressed. However, these barriers should be tackled more directly through tax reforms aimed at lowering the cost of entering paid work and reducing the fiscal burden on secondary earners. Providing better access to substitute care services is obviously a central requirement, whether through tax deductions or direct programming. Lahey has outlined a comprehensive set of recommendations for reducing the high marginal tax rates experienced by secondary earners in 
Canada, including a possible earned income tax credit or, alternatively, full deductibility for the costs of earning employment or business income (2005; see also Kesselman 2008). These could be implemented alongside refundable caregiver credits to neutralize any tax bias in favour of household production.

\section{REAL INCOME SPLITTING}

This chapter has offered a feminist intervention in the debate over income splitting by couples, a topic that is perennially troublesome for countries that treat individuals as separate taxpayers. It has highlighted the confusion that arises when the term 'income splitting' is used to describe both real and notional transactions between conjugal partners. I argue that differentiating these phenomena is the key to articulating a tax policy solution that coheres with gender-equality goals. That solution, I propose, is to recognize real income-splitting transactions more readily for tax purposes while eliminating notional income splitting rules in tax legislation. The practical implication of these principles will vary from country to country, depending on the details of their existing tax regimes.

As demonstrated in this chapter, no single tax reform can achieve significant progress toward gender equality in isolation, because women comprise a highly diverse group and because taxes interact with transfers and other policies, and with informal norms that influence behaviour in markets and families. In the Canadian context, however, I suggest the following set of complementary reforms: (1) repealing the pension income splitting rules; (2) repealing the attribution rules, subject to anti-avoidance provisions designed to catch transfers that have no economic substance and subject to the transferor realizing any accrued gains at the time of transfer; (3) replacing spousal dependency credits with a new refundable credit or transfer for caregivers who individually have low incomes; and (4) creating new tax or direct-spending measures to reduce the fiscal and other cost barriers that discourage secondary earners from undertaking paid labour. 


\section{REFERENCES}

Baines, S et al (2002) 'A Household-Based Approach to the Small Business Family' in D Fletcher (ed), Understanding the Small Family Business (London, New York: Routledge).

Baines S and J Wheelock (1998) 'Reinventing Traditional Solutions: Job Creation, Gender and the Micro-Business Household' 12 Work, Employment \& Society 579.

Bala, N (1989) 'Recognizing Spousal Contributions to the Acquisition of Degrees, Licenses and Other Career Assets: Toward Compensatory Support' 8 Canadian Journal of Family Law 23.

Benson, EJ (1969) Proposals for Tax Reform (Ottawa, Queen's Printer).

Blumberg, G (1971) 'Sexism in the Code: A Comparative Study of Income Taxation of Working Wives and Mothers' 21 Buffalo Law Review 49.

Brodie, J and Bakker, I (2008) Where Are the Women? Gender Equity, Budgets and Canadian Public Policy (Ottawa, Canadian Centre for Policy Alternatives).

Brooks, N (1996) 'The Irrelevance of Conjugal Relationships in Assessing Tax Liability' in J Head and R Krever (eds), Tax Units and the Tax Rate Scale (Burwood, Victoria: The Australian Tax Research Foundation).

Brown, DA (1997) 'Race, Class, and Gender Essentialism in Tax Literature: The Joint Return' 54 Washington \& Lee Law Review 1496.

Burton P, S Phipps and F Woolley (2007) 'Inequality Within the Household Reconsidered' in S Jenkins and J Micklewright (eds), Inequality and Poverty Re-examined (Oxford: Oxford University Press).

Canada Revenue Agency (1994, 26 August) Interpretation Bulletin IT-352R2: Employee's Expenses, Including Work Space in Home Expenses.

-- (2001, 14 August) Interpretation Bulletin IT-64R4: Corporations: Association and Control.

Canadian Feminist Alliance for International Action (undated) Gender-Responsive 
Budgeting and Upholding Canada's International Human Rights Commitments Essential in a Weakened Economy: 2009 Pre-Budget Submission of FAFIA.

Available at:

osgoode.yorku.ca/osgmedia.nsf/0/DF7C8633F3187F3E85257560005718B5/\$FILE/FAFIA _Submission_2009_Pre-Budget_Consultations.pdf.

Conservative Party of Canada (2008a) Policy Declaration. Available at www.conservative.ca/media/2008-PolicyDeclaration-e.pdf.

- - (2008b) True North Strong and Free: Stephen Harper's Plan for Canadians. Available at www.conservative.ca/media/20081007-Platform-e.pdf.

Danes, S and P Olson (2003) 'Women's Role Involvement in Family Businesses, Business Tensions, and Business Success' 16 Family Business Review 53.

Donnelly, M Magee, J and Young A (2000) 'Income Splitting and the New Kiddie Tax: Major Changes for Minor Children' 48 Canadian Tax Journal 978.

Eardley, T and A Cordon (1996) Low Income Self-Employment (Avebury).

Edgar, Tim (2008) ‘Building a Better GAAR’ 27 Virginia Tax Review 833.

Forman, J (1996) 'What Can Be Done About Marriage Penalties?' 30 Family Law Quarterly 1.

Fraser, N (1997) Justice Interruptus: Critical Reflections on the 'Postsocialist' Condition (New York, London: Routledge).

Gann, P (1980) 'Abandoning Marital Status as a Factor in Allocating Income Tax Burdens' 59 Texas Law Review 1.

Grassby, M ((2004) 'Two Income Couples: Presumption of Need for the Lower Income Spouse' 20 Canadian Journal of Family Law 321.

House of Commons Standing Committee on Finance (1999) For the Benefit of the Children: Improving Tax Fairness, Nineteenth Report of the Standing Committee on Finance, Sub-Committee on Tax Equity for Canadian Families with Dependent Children (Ottawa, Queen's Printer).

House of Commons Standing Committee on the Status of Women (2008) Towards 
Gender Responsive Budgeting: Rising to the Challenge of Achieving Gender Equality (Ottawa, House of Commons Canada). Available at www.parl.gc.ca.

Infanti, A (2009) 'Decentralizing Family: An Inclusive Proposal for Individual Tax Filing' (draft on file with author).

Kahng, L (2004) 'Innocent Spouses: A Critique of the New Tax Laws Governing Joint and Several Liability' 49 Villanova Law Review 261.

Kesselman, J (2008) Income Splitting and Joint Taxation of Couples: What's Fair (Montreal, Institute for Research on Public Policy). Available at www.irpp.org/fasttrak/index.htm.

Kornhauser, M (1993) 'Love, Money, and the IRS: Family, Income-Sharing, and the Joint Income Tax Return' 45 Hastings L.J. 63.

Lahey, K (1995) Women and Employment: Removing Fiscal Barriers to Women's Labour Force Participation (Ottawa: Status of Women Canada).

Lahey, K (2000) The Benefit/Penalty Unit in Income Tax Policy: Diversity and Reform, Study prepared for the Law Commission of Canada. Available at https://dalspace1.library.dal.ca/dspace/handle/10222/10400?show=full.

- - (2005) Women and Employment: Removing Fiscal Barriers to Women's Labour Force Participation (Ottawa, Status of Women Canada).

Langer, R (1994) 'Post Marital Support Discourse, Discretion, and Male Dominance' 12 Canadian Journal of Family Law 67.

Law Commission of Canada (2001) Beyond Conjugality: Recognizing and Supporting Close Personal Adult Relationships (Ottawa, Minister of Public Works and Government Services).

Law Commission of Ontario (2008) Division of Pensions Upon Marriage Breakdown (Toronto: Law Commission of Ontario). Available at www.lco-cdo.org.

Library of Parliament (2007) Income Splitting: A Brief Overview (Ottawa, Parliamentary Information and Research Service).

Luxton, M and L Vosko (1998) 'Where Women's Efforts Count: The 1996 Census Campaign and 'Family Politics' in Canada 1980-1995' 56 Studies in Political 
Economy 49.

McCaffery, E (1992) 'Taxation and the Family: A Fresh Look at Behavioral Gender Biases in the Tax Code' 40 UCLA Law Review 983.

Mintz, J (2008) 'Taxing Families: Does the System Need an Overhaul?' (Spring/Summer) IMFC Review 15.

Mossman, M (2008) 'Equity and "Family" Relationships: Cohabitation and Constructive Trusts' in M Gillen and F Woodman (eds), The Law of Trusts: A Contextual Approach, 2d (Toronto: Emond Montgomery) 775.

Papanek, H (1973) 'Men, Women and Work: Reflections on the Two-Person Career' 78 American Journal of Sociology 852.

Philipps, L (2002) 'Cracking the Conjugal Myths: What Does It Mean for the Attribution Rules?" 50 Canadian Tax Journal 1031.

- - (2008a) 'Helping Out in the Family Firm: The Legal Treatment of Unpaid Market Labor' 23 Wisconsin Journal of Law, Gender \& Society 65.

- - (2008b) "Silent Partners: The Role of Unpaid Market Labor in Families" 14 Feminist Economics 37.

Poirier, D and M Boudreau (1992) 'Formal Versus Real Equality in Separation Agreements in New Brunswick' 10 Canadian Journal of Family Law 239.

Rowe, B and G Hong (2000) 'The Role of Wives in Family Businesses: The Paid and Unpaid Work of Women' 13 Family Business Review 1.

Royal Commission on the Status of Women in Canada (1970) Report of the Royal Commission on the Status of Women in Canada (Ottawa, Information Canada).

Royal Commission on Taxation (1966) Report of the Royal Commission on Taxation (Ottawa, Queen's Printer).

Stephens M and J Ward-Batts (2004) 'The Impact of Separate Taxation on the IntraHousehold Allocation of Assets: Evidence from the U.K.' 88 Journal of Public Economics 1989.

Szabo, P (1997) Strong Families...Make A Strong Country (Ottawa: House of Commons 
Office of Paul Szabo, M.P.).

Schuetze, H (2006) 'Income Splitting Among the Self-Employed' 39 Canadian Journal of Economics 1195.

Weir, E (2007) Splitting All Income Would Worsen, Not Lessen Inequality (Ottawa, Canadian Centre for Policy Alternatives). Available at www.policyalternatives.ca.

Williams, J (2000) Unbending Gender: Why Work and Family Conflict and What to Do About It (New York: Oxford University Press.

Woolley, F (2007) 'Liability Without Control: The Curious Case of Pension Income Splitting' 55 Canadian Tax Journal 603.

Young, C (2000) What's Sex Got To Do With It? Tax and the 'Family' (Ottawa: Law Commission of Canada).

Zelenak, L (1994) 'Marriage and the Income Tax Act' 67 Southern California Law Review 339.

\section{Cases}

Cie Idéal Body v. R, [1989] 2 C.T.C. 187; 89 D.T.C. 5344 (Federal Court Trial Division).

Cullen v. Canada, [1985] 2 C.T.C. 2059; 85 D.T.C. 409 (Tax Court of Canada).

Emery v Canada , [2004] 1 CTC 2480; 2003 DTC 4034 (Tax Court of Canada).

Kuchirka (M.) v Canada, [1991] 1 C.T.C. 339; 91 D.T.C. 5156 (Federal Court TrialDivision).

Longtin v R., [2006] 5 C.T.C. 2323, 2006 D.T.C. 3254 (Tax Court of Canada).

Maduke Foods Ltd. v R., [1989] 2 C.T.C. 284; 89 D.T.C. 5458 (Federal Court Trial Division).

Morgan v Canada, [2008] 1 C.T.C. 2516; 2007 D.T.C. 1360 (Tax Court of Canada).

Neuman v Minister of National Revenue, [1998] 3 C.T.C. 177; 98 D.T.C. 6297; [1998] 1 S.C.R. 770, 225 (Supreme Court of Canada).

Prince v Canada, 2000 CarswellNat 1650; 2000 D.T.C. 3629 (Tax Court of Canada). 
Sauvé v R., [2007] 1 C.T.C. 2295; 2006 D.T.C. 3671 (Tax Court of Canada).

Schnurr v R., [2005] 1 C.T.C. 2213; 2004 D.T.C. 3531 (Tax Court of Canada).

Sedelnick Estate v. Minister of National Revenue, [1986] 2 C.T.C. 2102; 86 D.T.C. 1563 (Tax Court of Canada).

\section{Legislation}

Income Tax Act, R.S.C. 1985, c.1 (5 ${ }^{\text {th }}$ supp.), as am. 